Journal of Social Sciences (COES\&RJ-JSS)

ISSN (E): 2305-9249 ISSN (P): 2305-9494

Publisher: Centre of Excellence for Scientific \& Research Journalism, COES\&RJ LLC Online Publication Date: $1^{\text {st }}$ October 2018

Online Issue: Volume 7, Number 4, October 2018

https://doi.org/10.25255/jss.2018.7.4.260.276

\title{
Is Fair Value Accounting an Appropriate Measure of Today's Financial Instruments as more Firms Follow (IFRS)
}

\author{
Loay Salem Mohammad Al-Rahamneh \\ University of Jordan, School Of Business, Full-time Lecturer \\ I.rahamneh@ju.edu.jo \\ https://orcid.org/0000-0002-8273-5478
}

\begin{abstract}
:
The study aimed at identifying whether the fair value accounting is appropriate measure of today's financial instruments as more firms follow (IFRS). The sample of the study consisted of a number of Jordanian industrial joint stock companies listed in the Amman Stock Exchange, and 50 out of 78 companies randomly selected. The results show a positive effect of fair value accounting on the appropriateness of the financial statement data in Jordanian industrial joint stock companies away from the use of IFRS. Accordingly, the study recommended the need to provide the appropriate environment for the application of fair value accounting standards because of their importance appear in this study.
\end{abstract}

Keywords:

Fair Value Accounting, Financial Instruments, IFRS

\section{Citation:}

Al-Rahamneh, Loay Salem Mohammad (2018); Is fair value accounting an appropriate measure of today's financial instruments as more firms follow (IFRS); Journal of Social Sciences (COES\&RJ-JSS), Vol.7, No.4, pp:260-277; https://doi.org/10.25255/jss.2018.7.4.260.276. 


\section{Introduction}

The "fair value" is an economic term before it is a tool for accounting measurement, and its recent entry into the accounting world was a reflection of the development of economic theory in particular, in light of the tremendous economic developments in communications, technology and the metal trade. Rapid turnover of the financial instruments produced by the market economy movement in general (Al-Bashir, 2006; Alkalha et al., 2012; Obeidat et al., 2013; Masa'deh et al., 2015; Al-dalahmeh et al., 2018). The historical cost of the event, which represents the actual reality of the event at the time of exchange, is not in doubt as to its accuracy or validity at the moment of acquisition; rather, it raises doubts about the validity of the principle after the acquisition or the occurrence of the event, as the recorded value becomes something of the past that deviates slightly or substantially from its current value. From here, criticism of the historical cost principle has begun, as economic conditions characterized by a dynamic and ever-changing dynamic movement, and the purchasing power of the monetary unit changes by changing these conditions in different situations and then heading to fair value (Saleh, 2009).

Fair value in accordance with International Accounting Standards (IAS) defines the amount at which an asset can be exchanged or a debt settled between knowledgeable and willing parties on a purely commercial basis. The fair value is the best price at which the sale of the property (in an open market) can be made fully and unconditionally, or the corresponding cash equivalent at the valuation date, provided that there are several assumptions that the parties to the sale have sufficient information freely (Dietrich et al., 2001).

Fair value is the amount at which an asset can be exchanged or settled between parties willing to conclude a real and reasonable exchange transaction. International accounting standards have disclosed the components of the fair value definition that the fair value is determined on a given date and in accordance with changing market conditions from time to time. The definition of fair value includes "willing and informed parties", which means the willing purchaser, the buyer who is the catalyst for the purchase and not the obligor, or the excessive desire to buy at any price. The buyer makes the purchase in accordance with current market realities and expectations in this market. The seller is not forced to sell or excessive in the desire to sell at any price, this would be a catalyst to sell his investment properties at the best price can be obtained in the open market after the appropriate marketing procedures for sale, in addition to the informed parties, which means that both buyer and seller are Interested in knowledge and the knowledge of the nature and characteristics of the investment property, its actual and expected uses and the state of the market at the date of the financial position. The estimation of fair value is based on several principles. Hammad (2003) examined two principles for estimating fair value: If an active market exists, fair value is taken from the active market and not taken from others. In the absence of an active market, Methods are available under existing conditions.

In order to measure fair value, a set of basic information has to be provided. The study of this information, namely; the subject of exchange, the parties to the exchange process, 
the parties to the process, the free will of the parties to the exchange process, the knowledge of the parties involved in the exchange process, and the continuation of the two sides of the exchange process in the exercise of their activity without any direction to liquidate or reduce the volume of activity substantially. Several methods have dealt with these methods. The most important of these methods is the cost of replacement (replacement cost), which is defined as "the amount of cash (or equivalent) that an enterprise can incur if it wishes to buy back the assets it owns at the present time, or in what the entity may have of cash (or equivalent) when carrying out a commitment at the present time, in addition to the current market value known as "the amount of cash that an enterprise can obtain, If it has sold what it has Current value, which should reflect the prevailing market conditions at the time of the change", plus (net realizable value) which defined as the amount of money that can be obtained from the sale of assets in a negotiated process between willing and knowledgeable parties Less the costs of disposal of assets", plus the present value of cash flows which are defined as "the present value of estimated and expected cash flows from the continuing use of the asset" (Deloitte \& Touche, 2003).

The use of fair value has several advantages as the users of the financial statements need appropriate, reliable and comparable information to assess the financial position of the entity and the outcome of its business, so that such information is useful for them to make economic decisions. The most important of these problems is the absence of market prices for certain assets or the market price does not reflect the fair price, In addition to the complexity of certain accounting treatments of fair value, difficult in understanding and the lack of proper application of international accounting standards occur. More than 130 countries follow the International Financial Reporting Standards (IFRS), which have been set by the International Accounting Standards Board (IASB) (Jerry et al., 2015). As a result, the accounting philosophy and the bodies concerned with the development, modification and development of accounting principles, concepts and principles, including the International Accounting Standards Board (IASB), have begun to replace accounting principles based on fair value with the principle of historical cost. As a result, Jordan has adopted the International Financial Reporting Standards (IFRS). Therefore, it is necessary to reveal the reflection and impact of fair value on the financial indicators that measure the performance of Jordanian joint stock companies listed on the ASE, including the appropriateness and reliability of the financial statements, and the appropriateness of accounting information of great importance to decision-makers.

\section{Problem of the study}

In an extremely changing world with economic and financial developments, business organizations have faced many challenges. These challenges have shed a negative light on the realism and safety of accounting measurement and the prediction of variables that affect the value of an enterprise, in light of the concept and application of the historical cost approach. It is considered the best approach to the comprehensive identification of its assets and liabilities. Therefore, this study is intended to determine the importance of applying the fair value accounting method. Although the application of the fair value accounting method is the most recent alternative, the big companies face problems in the application process. 
That is why the study will try to answer the following questions:

1-Is there any impact to the application of fair value accounting in the appropriateness of the financial statements data in the Jordanian Public Shareholding industrial companies?

2-Is there an impact of the application of fair value accounting on the financial performance indicators related to the income statement (ordinary earnings per share, profit distribution ratio, ordinary earnings per share) in the financial statements of the Jordanian industrial joint stock companies?

3-Is there an impact on the application of fair value accounting on the financial performance indicators related to the financial position (trading ratio, liquidity ratio, debt ratio) in the financial statements of the Jordanian industrial joint stock companies?

\section{The importance of studying}

The Jordanian industrial sector is one of the strategic and vital sectors that contribute to the formation of the economy. Accordingly, the importance of this study lies in its attempt to examine the extent to which the application of fair value accounting affects the financial performance of the industrial joint-stock companies in Jordan and the expected impact on the financial performance of the industrial companies. In this study, the researcher will examine the application of fair value standards in the measurement process to the financial operations carried out by Jordanian industrial joint stock companies, and obstacles that may be involved in the application process.

Thus, the study highlights the importance of the following:

1-Statement of the effect of fair value accounting on the extent to which the use of fair value accounting affects the financial indicators of industrial companies, including their suitability and reliability.

2-To identify the factors and obstacles in using the fair market value of the Jordanian industrial companies.

3-The lack of research on this topic despite the vitality of this subject to the reality of accounting profession in Jordan and this is linked to the lack of adoption of accounting standards for the Jordanian environment and the absence of specific rules for professional behavior and lack of awareness of accountants.

\section{Objectives of the study}

The objectives of the study are to shed light on the subject of the study, as well as to provide some of the recommendations and suggestions that contribute to enrichment of the subject. It can also achieve a set of sub-objectives:

1-Recognition of the effect of applying fair value accounting on the appropriateness of the financial statement data in the Jordanian industrial joint stock companies.

2-Recognition of the impact of the application of fair value accounting on financial performance indicators related to the income statement (ordinary earnings per share, profit distribution ratio, ordinary earnings per share) in the financial statements of Jordanian industrial joint stock companies, apart from the use of the International Financial Reporting Standards (IFRS). 
3-Recognition of the impact of the application of fair value accounting on financial performance indicators related to the financial position (trading ratio, liquidity ratio, debt ratio) in the financial statements of the Jordanian industrial joint stock companies, away from the use of the International Financial Reporting Standards (IFRS).

\section{Study hypotheses}

The study is based on the following zero assumptions:

The first major hypothesis: There is no statistically significant effect at the level of ( $\alpha \leq$ 0.05 ) for the application of fair value accounting in the appropriateness of the financial statement data in the Jordanian public joint stock companies, away from the use of the International Financial Reporting Standards (IFRS).

The second main hypothesis: There is no statistically significant effect at the level of ( $\alpha \leq 0.05$ ) for the application of fair value accounting on the financial performance indicators related to the income statement (ordinary earnings per share, profit distribution ratio, ordinary earnings per share) in the financial statements of Jordanian industrial joint stock companies, international financial reporting (IFRS).

The third hypothesis: There is no statistically significant effect at the level of $(\alpha \leq 0.05)$ for the application of fair value accounting on the financial performance indicators related to the financial position (trading ratio, liquidity ratio, debt ratio) in the financial statements of the Jordanian industrial joint stock companies, financial reporting (IFRS).

\section{Methods of data collection}

To obtain the data needed for this study, two types of data were used:

First: Primary sources: obtained through the data received in the lists of the financial position of Jordanian joint stock companies to achieve the objectives of the study and test its hypotheses.

Second: Secondary sources: are books, journals, master's and doctoral studies, periodicals and others were reviewed in order to develop the theoretical framework for this study.

\section{Previous studies}

Several studies have addressed the importance of applying fair value accounting to the financial performance of companies and the most important problems facing them. Study of (Glover et al., 2017), examined the fair value measurements of auditing and other complex estimates (below), which has received considerable attention from regulators, practitioners and researchers, and by using a survey, they collected data from audit partners with experience in fisheries management for more information in areas not fully explored in previous literature. Specifically, the researchers expanded the literature by providing a deeper understanding of the following areas: the use of different technical approaches by the auditors to test high-risk fair value risks, the use of service auditors pricing and valuation specialists and how the challenges differ from financial auditing to non-financial value. Useful insights in reconciling results that appear inconsistent in the previous studies and provides significant implications for future research, organization and standard setting.

Study of (Demerjian et al., 2016), examined how fair value accounting affects the design of debt contracts, specifically the use and definition of financial commitments in private 
loan contracts. Using Savas' 159 credits in our position, a small but significant proportion of loans (14.5\%) modify the definitions of the Covenant to exclude fair value effects on fair value. Only a limited number of these amendments excludes elected assets at fair value (less than $7 \%$ ), while all elected liabilities are derecognized at fair value, and the researchers noted that the amendment to the definition of the Covenant is not related to previous fair value elections. With the problems of common incentives attributed to fair value accounting and which differ negatively with the benefits attributed to fair value accounting. Their results indicate that fair value accounting is not uniformly detrimental to debt contracting and fair value adjustments are included when they are likely to improve the performance measurement.

Salzsieder (2016) study, which reports the results of an experiment aimed at providing empirical evidence relating to fair value shopping opinion. Experience provides preliminary evidence that managers are likely to shop for fair value opinions from external valuation experts in the absence of disclosure requirement for the board of directors or auditor. Disclosure becomes a significant deterrent when the beneficiary of the Opinion Shop is seen as the manager. However, disclosure is an ineffective deterrent when the beneficiary is seen as a contributor. Study of Mclnnis et al. (2013), examines whether fair value income provides a more useful summary measure of banks' performance than net income in accordance with generally accepted accounting principles (GAAP), the findings if the study reveals that the fair value income lowers the weight of valuation in the composition of stock prices and it lowers the weight of incentives in contracts for compensation for net income of GAAP. Moreover, the fair value income is less comparable and less predictable than the generally accepted net income. The results also show that the relative poor performance of revenue values In general, these results are consistent with fair value income as a less useful summary measure of banks' performance than net GAAP income for valuation purposes. This is partly due to the lower reliability of reported fair values.

Study of Al-Ja'arat (2012) focused on the results of the study of academic researchers, practitioners and bodies prepared for the standards that assess the fair value requirements. The study aims at reviewing the published studies on the usefulness of information regarding the fair value of investors in the financial markets, the issuance and recognition of future standards. The study also aimed to develop new evidence to confirm that the expressed and recognized fair values are guiding values for investors. The study has presents a number of recommendations, the most important of which is the need to provide dependable and reliable information to investors, with the need to improve the relevance and reliability of the fair values of assets and liabilities through new measurements, and disclosure standards and recognition that extends to a wider range of assets and liabilities in the future, the result of study is there are impact of fair value accounting on the appropriateness of the financial statement data.

Study of Procházka (2011), the researcher examines that fair value measurement that has become prevalent with financial reporting over the past 20 years, under fair value accounting, the entities are required or permitted to measure certain assets and liabilities at their fair values at the reporting date, Is a market-based default value, which 
is not always directly observable. The discussion about the usefulness of fair value accounting for the financial crisis and the economic crisis arose in the years 2007 to 2009. Fair value accounting liabilities insist that existing financial reporting, the other hand, there are several important views in favor of fair value accounting. The aim of this paper is to contribute to the actual debate as to whether fair value accounting plays the role of the messenger or the engine in fair value accounting, in the recent financial crisis and the subsequent economic recession, in the analysis of the characteristics of fair value accounting in economic terms. And the result is significant impact of the application of fair value accounting on financial performance indicators related to the financial position.

Study of Galera, Carmen, \& Areza (2010) considers that a fair value approach should be used to assess real estate assets. The choice of using this or another approach may affect the quality of published financial reports in response to information demands from stakeholders. In this study, we will examine whether the fair value valuation, in the real estate context, improves the usefulness of the financial reports of the construction company. To this end, the researchers have addressed a questionnaire to financial managers on the relevance, reliability and applicability of this evaluation standard. Based on the respondents' opinion, the results show that the fair value model would improve the usefulness of the financial reports to assess the Company's reliability and would improve the comparability, timeliness and understanding of such reports, and the result is there are impacts of fair value accounting on the appropriateness of the financial statement.

Study of Weighing (2009) measures the difficulties arising from the credit crunch on fair value and accounting to the market and called for the suspension of accounting rules fair value in favor of historical cost accounting. Others argue that fair value accounting is not the cause of the crisis but rather documents the effects of bad investment decisions. The author suggests some reasonable reforms for financial reporting, although many mortgages and other financial instruments lead, some believe that frozen financial markets have caused asset prices to fall below their real value, prompting some banks to insolvency and forced the sale of assets at low prices. In response, some critics called for the suspension of fair value accounting rules in favor of historical cost accounting. However, distressed assets recorded at historical cost ignore the reality and distort the reliability of the information that capital providers require to allocate effective capital.

Study of Mebaidine \& Al-Bishtawi (2008) conducted in Jordan, focused on the financial intermediaries sector to determine the extent to which fair value accounting affects the appropriateness and reliability of financial statements in Jordanian financial intermediaries. The basis of accounting measurement is based on historical cost. A number of results have been obtained through this study: The majority of the individuals in kind have confirmed that the accounting information prepared at fair value is more suitable for decision makers in the brokerage firms, in addition to the fact that the accounting information prepared at fair value is more reliable. 
Study of Matar \& Sweiti (2006), which was applied to the Jordanian public shareholding companies, aims to demonstrate the effect of application of accounting on fair value in the fields of recognition and measurement on the prices of shares of companies operating in this sector. The study also presented some fair value applications for investments in Real Estate Property The recommendations of this study are that supervisors, supervisors, accountants and internal and external auditors must exercise caution in applying fair value with respect to the standard $(40,39)$ when preparing and auditing published financial statements.

Study of Al-Tarayrah (2006), aimed at the banks operating in Jordan to shed light on the most important rules for disclosure of fair value in accordance with international accounting standards and to construct the related disclosure index in relation to the financial statements of banks. The ASE has these rules. The researcher concluded that there are some differences between the fair value disclosure requirements of the Central Bank of Jordan and the International Accounting Standards, as well as the noncompliance of banks listed on the Amman Stock Exchange to disclose disclosure rules related to the fair value of financial assets and liabilities, risks and financial instruments.

Study of Rosa \& Bertoni (2006) conducted in Italy, aimed to demonstrate the importance of value in the study of fair value, especially in the European environment. It also described the theoretical background of the options made available by the International Standards Board: historical cost and fair value accounting for measuring the financial performance of companies. The study concluded that the use of these two options (historical cost and fair value accounting) together are manifestations of inconsistency, in addition to the fact that the international financial reporting standards, which are mandatory for all EU companies, focus heavily on fair value as a means of improving real representation. The fair financial situation of the companies is added to the performance evaluation of those companies.

Nash study (2003), the purpose of this study was to determine the impediments to the application of fair value accounting when measuring assets and liabilities, especially nonfinancial assets and liabilities. The study concluded that the definition of fair value is inaccurate because it depends on price not on value, and that fair value concerns intangible assets, despite their importance and dominance at present.

\section{What distinguishes this study?}

The most important thing which makes this study distinct from previous studies is: -Different study variables.

-The study sample represented by the Jordanian industrial joint stock companies listed at the Amman Stock Exchange during the period (2013-2016).

-Few studies related to the subject of the study.

\section{Methodology of the study}

The descriptive analytical approach was followed in this study by clarifying the most important concepts related to fair value accounting and agreed international accounting standards, testing hypotheses, reaching conclusions and recommendations. 


\section{The society of the study and its mentality}

The study population consists of all the Jordanian industrial joint stock companies listed in the Amman Stock Exchange is 78. The industrial companies were chosen because they represent the largest sectors of the Amman market. The sample of the study was based on a random sample consisting of a number of Jordanian industrial joint stock companies listed in the Amman Stock Exchange 50 out of 78 companies, representing $65 \%$ of the study society to determine whether the Fair value is an appropriate measure of current financial instruments as more companies comply with IFRS.

\section{The limits of the study}

Spatial Boundaries: The Jordanian industrial companies supporting the public listed in the Amman Stock Exchange 50 out of 78 companies,

Time Limits: During the financial period 2013/2016.

\section{Statistical processing}

The Statistical Package for Social Sciences (SPSS) was used in conducting these analyzes and statistical tests. In order to achieve the objectives of the study, the following statistical methods were used:

- Descriptive statistics: In order to present the characteristics of the sample members and describe their answers, by using the following:

-Percentage: It was used to measure the relative frequency distributions of the characteristics of the sample members and their responses to the terms of the questionnaire.

-The arithmetic mean: It was used as the most prominent measure of central tendency to measure the average responses of respondents to the questionnaire questions.

-Standard Deviation: It was used as a dispersion measure to measure the deviation in the responses of the sample members from their arithmetic mean.

Analytical Statistics:

-Multiple Regression Analysis method used to show the effect of independent variables on dependent variables.

-The level of significance $(\alpha)$ : (0.05) was adopted as a maximum of the level of significance and if the level of significance $(0.05)$ or less, then there is a relationship of statistical significance, but if the level of significance greater than (0.05), there is no significant relationship Statistic.

\section{Testing hypotheses}

\section{The main first hypothesis}

There is no statistically significant effect at the level of $(\alpha \leq 0.05)$ for the application of fair value accounting in the appropriateness of the financial statement data in the Jordanian public joint stock companies, away from the use of the International Financial Reporting Standards (IFRS).

Multiple regression analysis was used to validate the validity of the model to test the first main hypothesis. 
Journal of Social Sciences (COES\&RJ-JSS), 7(4), pp.260-276

Table 1. Results of multiple regression analysis to confirm the validity of the model to test the first main hypothesis

Variables Entered/Removed

\begin{tabular}{|l|l|l|l|}
\hline Model & $\begin{array}{c}\text { Variables } \\
\text { Entered }\end{array}$ & $\begin{array}{c}\text { Variables } \\
\text { Removed }\end{array}$ & Method \\
\hline 1 & FF $^{\mathrm{a}}$ &. & Enter \\
\hline
\end{tabular}

a. All requested variables entered.

b. Dependent Variable: AA

Model Summary

\begin{tabular}{|l|r|r|r|c|}
\hline Model & $\mathrm{R}$ & R Square & $\begin{array}{c}\text { Adjusted } \\
\text { R Square }\end{array}$ & $\begin{array}{c}\text { Std. Error } \\
\text { of the } \\
\text { Estimate }\end{array}$ \\
\hline 1 & $.719^{\mathrm{a}}$ & .516 & .507 & 1.9537 \\
\hline
\end{tabular}

a. Predictors: (Constant), FF

ANOVA

\begin{tabular}{|c|c|c|c|c|c|c|}
\hline & & $\begin{array}{c}\text { Sum of } \\
\text { Squares }\end{array}$ & df & $\begin{array}{l}\text { Mean } \\
\text { Square }\end{array}$ & $\mathrm{F}$ & Sig. \\
\hline \multirow[t]{3}{*}{1} & Regression & 207.785 & 1 & 207.785 & 54.436 & $.000^{2}$ \\
\hline & Residual & 194.668 & 51 & 3.817 & & \\
\hline & Total & 402.453 & 52 & & & \\
\hline
\end{tabular}

a. Predictors: (Constant), FF

b. Dependent Variable: AA

Coefficients $^{\mathbf{a}}$

\begin{tabular}{|c|c|c|c|c|c|}
\hline \multirow[b]{2}{*}{ Model } & \multicolumn{2}{|c|}{$\begin{array}{l}\text { Unstandardized } \\
\text { Coefficients }\end{array}$} & \multirow{2}{*}{$\begin{array}{c}\text { Standardi } \\
\text { zed } \\
\text { Coefficien } \\
\text { ts }\end{array}$} & \multirow{2}{*}{$\mathrm{t}$} & \multirow[b]{2}{*}{ Sig. } \\
\hline & B & Std. Error & & & \\
\hline (Constant) & $-4.42 \mathrm{E}-03$ & 3.315 & & -.001 & .999 \\
\hline FF & .304 & .041 & .719 & 7.378 & .000 \\
\hline
\end{tabular}

a. Dependent Variable: AA

*Statistical significance at the level of $(\alpha \leq 0.05)$

Determination factor $(\mathrm{R} 2)=0.516$

The validity of the model is shown to test the first main hypothesis based on the high value of $(F)$ calculated (54.436) with a probability value of 0.000 which is less than the significance level $(\alpha \leq 0.05)$. It is clear from the same table that the independent 
Is fair value accounting an appropriate measure of today's financial instruments....

dimensions (51.6\%) of the variance in the dependent variable reflects the appropriateness of the financial statement data, which indicates that there is a positive effect of fair value accounting on the appropriateness of the financial statement data in the Jordanian public joint stock companies, Financial reporting (IFRS).

The second hypothesis: There is a statistically significant effect on the application of fair value accounting on the financial performance indicators related to the income statement (ordinary earnings per share, profit distribution ratio, ordinary earnings per share) in the financial statements of Jordanian industrial joint stock companies.

Multiple regression analysis was used to validate the validity of the model to test the second main hypothesis.

Table 2. Multiple regression analysis results to confirm the validity of the model to test the second main hypothesis

\section{Variables Entered/Removed}

\begin{tabular}{|l|l|l|l|}
\hline Model & $\begin{array}{c}\text { Variables } \\
\text { Entered }\end{array}$ & $\begin{array}{c}\text { Variables } \\
\text { Removed }\end{array}$ & Method \\
\hline 1 & FF $^{\mathrm{a}}$ & & Enter \\
\hline
\end{tabular}

a. All requested variables entered.

b. Dependent Variable: BB

Model Summary

\begin{tabular}{|l|r|r|r|c|}
\hline Model & $\mathrm{R}$ & R Square & $\begin{array}{c}\text { Adjusted } \\
\text { R Square }\end{array}$ & $\begin{array}{c}\text { Std. Error } \\
\text { of the } \\
\text { Estimate }\end{array}$ \\
\hline 1 & $.663^{\mathrm{a}}$ & .439 & .428 & 2.3055 \\
\hline
\end{tabular}

a. Predictors: (Constant), FF

ANOVA $A^{b}$

\begin{tabular}{|ll|r|r|r|r|r|}
\hline \multicolumn{1}{|c|}{ Model } & $\begin{array}{c}\text { Sum of } \\
\text { Squares }\end{array}$ & df & $\begin{array}{c}\text { Mean } \\
\text { Square }\end{array}$ & \multicolumn{1}{c|}{$\mathrm{F}$} & Sig. \\
\hline 1 & Regression & 212.056 & 1 & 212.056 & 39.896 & $.000^{\mathrm{a}}$ \\
& Residual & 271.076 & 51 & 5.315 & & \\
& Total & 483.132 & 52 & & & \\
\hline
\end{tabular}

a. Predictors: (Constant), FF

b. Dependent Variable: BB 
Journal of Social Sciences (COES\&RJ-JSS), 7(4), pp.260-276

\section{Coefficients $^{\mathrm{a}}$}

\begin{tabular}{|c|c|c|c|c|c|}
\hline \multirow[b]{2}{*}{ Model } & \multicolumn{2}{|c|}{$\begin{array}{l}\text { Unstandardized } \\
\text { Coefficients }\end{array}$} & \multirow{2}{*}{$\begin{array}{c}\text { Standardi } \\
\text { zed } \\
\text { Coefficien } \\
\text { ts }\end{array}$} & \multirow[b]{2}{*}{ t } & \multirow[b]{2}{*}{ Sig. } \\
\hline & B & Std. Error & & & \\
\hline (Constant) & 2.916 & 3.912 & & .745 & .459 \\
\hline FF & .307 & .049 & .663 & 6.316 & .000 \\
\hline
\end{tabular}

a. Dependent Variable: BB

*Statistical significance at the level of ( $\alpha \leq 0.05)$

Determination factor $(\mathrm{R} 2)=0.439$

The validity of the model to test the second main hypothesis based on the high value of (F) calculated (39.896) with a probability value $(0.000)$ is lower than the level of significance $(\alpha \leq 0.05)$. It is clear from the same table that the independent dimensions (Average return on equity, profit distribution ratio, ordinary earnings per share), which indicates a statistically significant impact of the application of fair value accounting On the financial performance indicators relating to the statement of income (ordinary earnings per share, the distribution ratio) Share profit) in the financial statements of the Jordanian industrial joint stock companies, away from the use of the International Financial Reporting Standards (IFRS).

The third hypothesis: There is a statistically significant impact of the application of fair value accounting on the financial performance indicators related to the financial position (trading ratio, liquidity ratio, debt ratio) in the financial statements of Jordanian industrial joint stock companies.

Multiple regression analysis was used to validate the validity of the model to test the third main hypothesis.

Table 3. Results of multiple regression analysis to confirm the validity of the model to test the third main hypothesis

\section{Variables Entered/Removed}

\begin{tabular}{|l|l|l|l|}
\hline Model & $\begin{array}{c}\text { Variables } \\
\text { Entered }\end{array}$ & $\begin{array}{c}\text { Variables } \\
\text { Removed }\end{array}$ & Method \\
\hline 1 & FF $^{\mathrm{a}}$ & & Enter \\
\hline
\end{tabular}

a. All requested variables entered.

b. Dependent Variable: DD 
Is fair value accounting an appropriate measure of today's financial instruments....

\section{Model Summary}

\begin{tabular}{|l|r|r|r|r|}
\hline Model & $\mathrm{R}$ & R Square & $\begin{array}{c}\text { Adjusted } \\
\text { R Square }\end{array}$ & $\begin{array}{c}\text { Std. Error } \\
\text { of the } \\
\text { Estimate }\end{array}$ \\
\hline 1 & $.912^{\mathrm{a}}$ & .832 & .828 & 1.8259 \\
\hline
\end{tabular}

a. Predictors: (Constant), FF

ANOVA

\begin{tabular}{|c|c|c|c|c|c|c|}
\hline Model & & $\begin{array}{l}\text { Sum of } \\
\text { Squares }\end{array}$ & df & $\begin{array}{l}\text { Mean } \\
\text { Square }\end{array}$ & $\mathrm{F}$ & Sig. \\
\hline \multirow[t]{3}{*}{1} & Regression & 839.660 & 1 & 839.660 & 251.842 & $.000^{\mathrm{a}}$ \\
\hline & Residual & 170.038 & 51 & 3.334 & & \\
\hline & Total & 1009.698 & 52 & & & \\
\hline
\end{tabular}

a. Predictors: (Constant), FF

b. Dependent Variable: DD

Coefficients $^{\mathrm{a}}$

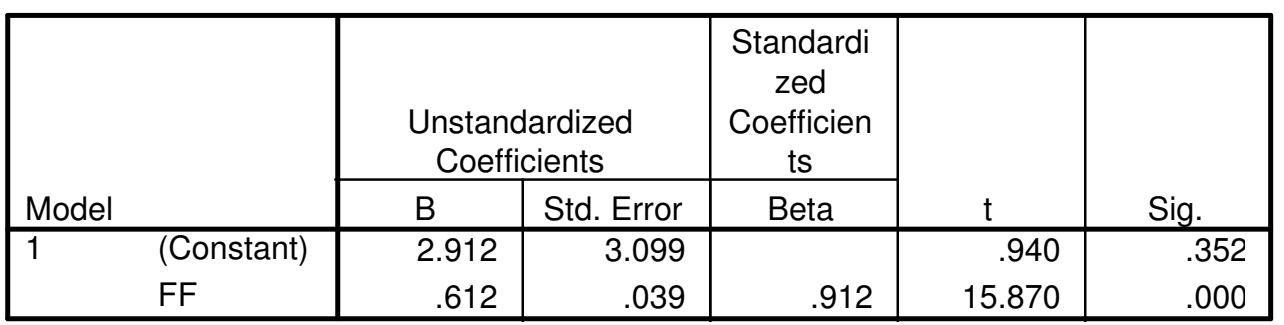

a. Dependent Variable: DD

*Statistical significance at the level of $(\alpha \leq 0.05)$

Determination factor $(\mathrm{R} 2)=0.832$

The validity of the model to test the first main hypothesis is based on the high value of (F) calculated $(251,842)$ with a probability value $(0.000)$ which is less than the level of significance $(\alpha \leq 0.05)$. It is clear from the same table that the independent dimensions (Fair value) in this model explain $83.2 \%$ of the variance in the dependent variable. The financial performance indicators related to the statement of financial position (ratio, liquidity ratio, debt ratio), indicating a statistically significant effect of applying fair value accounting to indicators Financial performance related to the statement of financial position (percentage of trading, percentage of assets) The ratio of indebtedness) in the financial statements of the Jordanian industrial joint stock companies, away from the use of the International Financial Reporting Standards (IFRS). 


\section{Conclusions and recommendations}

The results of the study were identified as a response to the questions that were raised. This is the problem of the study after the collection of the necessary information by means of the study tool. A number of results were reached, in light of which the researcher made a number of recommendations. Results of this study are as follows:

\section{Results}

The results of the analysis and hypothesis testing can be summarized as follows:

\section{The first question}

Is there an impact of the application of fair value accounting on the appropriateness of the financial statement data in the Jordanian public joint stock companies, away from the use of IFRS, (and answering this question is the answer to the hypothesis of the first main study). The statistical analysis shows that there is a positive impact of fair value accounting on the appropriateness of the financial statement data in the Jordanian public shareholding companies, away from the use of IFRS, this result is similar to the study (Galera, Carmen, \& Areza, 2010).

\section{The second question}

Is there an impact on the application of fair value accounting on the financial performance indicators relating to the income statement (ordinary earnings per share, profit distribution ratio, ordinary earnings per share) in the financial statements of the Jordanian industrial joint stock companies, away from the use of IFRS, the answer for this question is to the hypothesis of the second main study. The statistical analysis shows that the effect of applying fair value accounting on the financial performance indicators related to the income statement (ordinary earnings per share, profit distribution ratio, ordinary earnings per share) is reflected in the financial statements of Jordanian industrial joint stock companies, this result is similar to the study (Al-Ja'arat, 2012).

\section{The third question}

Is there an impact on the application of fair value accounting on financial performance indicators related to the financial position (trading ratio, liquidity ratio, debt ratio) in the financial statements of Jordanian industrial joint stock companies, away from the use of IFRS? This question is the answer to the hypothesis of the third main study. The statistical analysis shows that there is a statistically significant impact of the application of fair value accounting on financial performance indicators related to the financial position (trading ratio, fast liquidity ratio, debt ratio) in the financial statements of Jordanian industrial joint stock companies. , this result is similar to the study (Procházka, 2011).

\section{Recommendations}

In light of the findings of the study, the researcher presents a set of recommendations: 1. The need to provide an environment conducive to the application of standards of fair value accounting because of its importance and it was approved by this study.

2. Appointing experienced accountants and financial managers in the application of fair value standards.

3. The results of this study should be circulated to the relevant and interested parties. 
Is fair value accounting an appropriate measure of today's financial instruments....

4. Holding seminars, conferences and special education programs in relation to fair value to improve the awareness of employees of Jordanian industrial companies.

5. Conduct other studies similar to the subject of this study, with different variables related to the questions of the study.

6. Several researchers consider the information systems and in particular the information technology (IT) and its flexibility as an enabler to achieve the desired competitive advantages, and as a crucial support to operational and strategic business decisions (Masa'deh \& Kuk, 2007, 2009; Al-Dmour et al., 2015; Masa'deh, et al., 2016; Alenezi, et al., 2017; Obeidat, et al., 2017; Abualoush et al., 2018; Masa'deh, et al., 2018); thus further research is required to examine the role of such IT applications in enhancing the accounting managerial decisions.

\section{References}

Abualoush, S., Obeidat, A., \& Tarhini, A. (2018). The Role of Employees' Empowerment as an Intermediary Variable between Knowledge Management and Information Systems on Employees' Performance. VINE Journal of Information and Knowledge Management Systems, 48(2), 217-237.

Al-Bashir, M. (2006). Fair Value and Jordanian Legislation Relating to Accounting and Auditing Profession, Professional Scientific Conference of the Association of Chartered Accountants of Jordan, Amman, Jordan.

Al-dalahmeh, M., Khalaf, R., \& Obeidat, B. (2018). The Effect of Employee Engagement on Organizational Performance via the Mediating Role of Job Satisfaction: The Case of IT Employees in Jordanian Banking Sector. Modern Applied Science, 12(6), 17-43.

Al-Dmour, R., Obeidat, B., \& Almajali, D. (2015). The Practice of HRIS Applications in Business Organizations in Jordan: An Empirical Study. 4th Scientific \& Research Conference on New Trends in Business, Management and Social Sciences (COES\&RJTK15/1).

Alenezi, H., Tarhini, A., Alalwan, A., \& Al-Qirim, N. (2017). Factors Affecting the Adoption of E-Government in Kuwait: A Qualitative Study. Electronic Journal of e-Government, 15(2), 84-102.

Al-Ja'arat, K. (2012). Development of a Revised Accounting Standard for IAS 36 Related to Impairment of Assets Resulting in Improvement of Qualitative Transactions of Accounting Information. Unpublished Doctor Letter, Amman Arab University for Graduate Studies, Amman, Jordan.

Alkalha, Z., Al-Zu'bi, Z., Al-Dmour, H., \& Alshurideh, M. (2012). Investigating the Effects of Human Resource Policies on Organizational Performance: An Empirical Study on Commercial Banks Operating in Jordan. European Journal of Economics, Finance and Administrative Sciences, 51, 44-64.

Al-Tarayrah, J. (2006). The Modern Approach to Accounting Theory of the Concept of Fair Value and its Effect on Financial Reporting of Financial Statements of Banks Operating in Jordan. Unpublished Master Thesis, Amman Arab University, Amman, Jordan.

Deloitte, T., \& Touche, T. (2003). Comparison of Canadian GAAP \& International Accounting Standards, 30th April. http;//www. iasplus.com/country/canada.htm.

Demerjian, P., Donovan, J., \& Larson, C. (2016). Fair Value Accounting and Debt Contracting: Evidence from Adoption of SFAS. Journal of Accounting Research, 54(4), 1041-1076. 
Dietrich, J.R., Harris, M.S., \& Muller, K.A. (2001). The Reliability of Investment Property Fair Value Estimates. Journal of Accounting and Economics, 30(2), 125-158.

Galera, A., Carmen, M., \& Ariza, R. (2010). Fair Value of Real Estate and Utility of Financial Statements of Construction Companies. International Real Estate Review, 13(3), 323-350.

Glover, S., Taylor, M., \& Wu, Y-J. (2017). Current Practices and Challenges in Auditing Fair Value Measurements and Complex Estimates: Implications for Auditing Standards and the Academy. AUDITING, A Journal of Practice \& Theory, 36(1), 63-84.

Hammad, T. (2003). Fair Value Accounting, Dar Al Ketub, Alexandria, Egypt.

Jerry, J., Weygand Donald E. Kieso, \& Terry D. Warfield (2015). Intermediate Accounting: IFRS Edition, Wiley Publisher.

Masa'deh, R., \& Kuk, G. (2009). Antecedents and Intermediaries between Strategic Alignment and Firm Performance. Conference of the Academy of Management Annual Meeting (AOM), Illinois, Chicago, USA.

Masa'deh, R., \& Kuk, G. (2007). A Causal Model of Strategic Alignment and Firm Performance. European Conference on Information Systems (ECIS), Switzerland.

Masa'deh, R., Alrowwad, A., Alkhalafat, F., Obeidat, O., \& Abualoush, S. (2018). The Role of Corporate Social Responsibility in Enhancing Firm Performance from the Perspective of IT Employees in Jordanian Banking Sector: The Mediating Effect of Transformational Leadership. Modern Applied Science, 12(7), 1-26.

Masa'deh, R., Obeidat, B., \& Tarhini, A. (2016). A Jordanian Empirical Study of the Associations among Transformational Leadership, Transactional Leadership, Knowledge Sharing, Job Performance, and Firm Performance: A Structural Equation Modelling Approach. Journal of Management Development, 35(5), 681-705. https://doi.org/10.1108/JMD-09-2015-0134.

Masa'deh, R., Tayeh, M., \& Al-Jarrah, I. (2015). Accounting vs. Market-based Measures of Firm Performance Related to Information Technology Investments. International Review of Social Sciences and Humanities, 129-145.

Matar, M., \& Sweiti, M. (2006). The Effect of Using the Fair Value Measurement Methodology. Study of the Seventh Professional Scientific Conference of the Association of Chartered Accountants of Jordan, Amman, Jordan.

Mclnnis, J., Yu, Y., \& Yust, C. (2013). Is Fair Value Income a More Useful Summary Measure for Banks' Performance than GAAP Net Income?, http: http://jar.acct.nccu.edu.tw, 16/4/2016.

Mebaidine \& Al-Bishtawi, A. (2008). The Effect of Fair Value Accounting on the Suitability and Reliability of Financial Data in Jordanian Brokerage Companies. Suez Canal University Journal, 1(15), 25-43.

Nash, H. (2003). Accounting for the Future, a Disciplined Approach to Value-Added Accounting. Available on: http://home.sprintmail.com.

Obeidat, B., El-Rimawi, S., Maqableh, M., \& Al-Jarrah, I. (2013). Evaluating the Profitability of the Islamic Banks in Jordan. European Journal of Economics, Finance and Administrative Sciences, 56, 27-36.

Obeidat, B., Tarhini, A., \& Aqqad, N. (2017). The impact of intellectual capital on innovation via the mediating role of knowledge management: A structural equation modeling approach. International Journal of Knowledge Management Studies, 8(3/4), 273-298. 
Procházka, D. (2011). The Role of Fair Value Measurement in the Recent Financial. Prague Economic Papers Journal, 1(4), 71-88.

Rosa, M., \& Bertoni, B. (2006). Measuring Balance Sheet Conservatism: Empirical Evidence from Italian First Time Adopters of IFRS. Proceedings of the International Conference Emerging Issues in International Accounting and Business, 22(1), 33-54.

Saleh, A. (2009). The Effect of Accounting Standards on Fair Value on the Specific Characteristics of Accounting Information in the Global Financial Crisis. Journal of the Faculty of Commerce for Scientific Research, 46(2), 37-98.

Salzsieder, L. (2016). Fair Value Opinion Shopping. Behavioral Research in Accounting, 28(1), 57-66.

Weighing,T., (2009). Fair Value, https://doi.org

\section{About the Author}

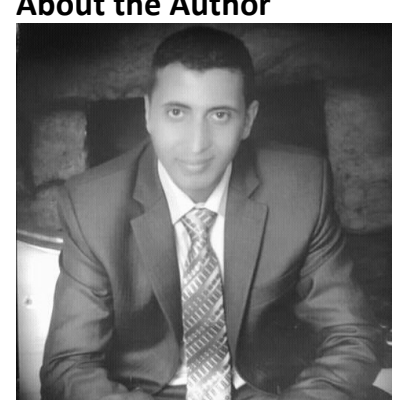

Loay S. Alrahamneh is a full-time lecturer working at university of Jordan, School of business. He was born in Yarqa, Jordan in 1982. He received the General Secondary Certificate in 2000. Then he received the B.Sc and M.sc degrees in Accounting from University of Jordan in 2005, and 2012, respectively.

He worked as an accountant in Jordan new cable company in 2005. Then he worked in university of Jordan in different positions: as an internal auditor in 2006, chief of internal audit division in 2010, and assistant manager in 2013. In 2014, He joined the department of accounting, university of Jordan as a lecturer.

His current research interests include the differences between IFRS and GAAP and how they affect decision-making; and corporate governance.

He would like to thank his mother called Nejmh for the support he got, and still gets to be a good man in society and to have achievements in academic or managerial life. 